\title{
Synthesis and cytotoxicity evaluation of granular magnesium substituted $\beta$-tricalcium phosphate
}

\author{
Débora dos Santos TAVARES ${ }^{1}$, Leticia de Oliveira CASTRO², Gloria Dulce de Almeida SOARES ${ }^{3}$, Gutemberg Gomes \\ ALVES $^{4}$, José Mauro GRANJEIRO 5
}

\begin{abstract}
1- DDS, MSc, PhD, Professor, Sergipe Federal University, Lagarto, SE, Brazil.
2- Graduate student, Chemistry, Department of Cell and Molecular Biology; Cell Therapy Center UPC-HUAP, Fluminense Federal University, Niterói, RJ, Brazil.

3- Eng, MSc, PhD, Professor, Department of Metallurgical and Materials Engineering, COPPE, Rio de Janeiro Federal University, Rio de Janeiro, RJ, Brazil.

4- DDS, MSc, PhD, Professor, Department of Cell and Molecular Biology, Fluminense Federal University, Niterói, RJ, Brazil.

5- DDS, MSc, PhD, Senior researcher, Bioengineering sector, National Institute of Metrology, Quality and Technology - INMETRO, Duque de Caxias, RJ, Brazil; Professor, Dental School, Fluminense Federal University, Niterói, RJ, Brazil.
\end{abstract}

\begin{abstract}
Corresponding address: José Mauro Granjeiro - Pesquisador Sênior - Diretoria de Programas, Instituto Nacional de Metrologia, Qualidade e Tecnologia - Av. Nossa Senhora das Graças, 50 - Prédio 6 - Sala da DIPRO, 1 Andar - Xerém - Duque de Caxias - Rio de Janeiro - RJ - $25250-020$ - Brasil - Phone: +55-21-2145-3320 - e-mail: jmgranjeiro@inmetro.gov.br
\end{abstract}

Submitted: February 14, 2012 - Modified: September 21, 2012 - Accepted: January 3, 2013

\section{ABSTRACT}

\begin{abstract}
O bjective: The aim of this study was to produce dense granules of tricalcium phosphate $(\beta-T C P)$ and magnesium $(\mathrm{Mg})$ substituted $\beta-\mathrm{TCP}$, also known as $\beta$-TCMP $(\mathrm{Mg} / \mathrm{Ca}=0.15$ $\mathrm{mol})$, in order to evaluate the impact of $\mathrm{Mg}$ incorporation on the physicochemical parameters and in vitro biocompatibility of this novel material. Material and Methods: The materials were characterized using X-ray diffraction (XRD), infrared spectroscopy (FTIR), electron microscopy and inductively coupled plasma (ICP). Biocompatibility was assayed according to ISO 10993-12:2007 and 7405:2008, by two different tests of cell survival and integrity (XTT and CVDE). Results: The XRD profile presented the main peaks of $\beta$-TCP (JCPDS 090169) and $\beta$-TCMP (JCPDS 130404). The characteristic absorption bands of TCP were also identified by FTIR. The ICP results of $\beta$-TCMP granules extract showed a precipitation of calcium and release of $\mathrm{Mg}$ into the culture medium. Regarding the cytotoxicity assays, $\beta$-TCMP dense granules did not significantly affect the mitochondrial activity and relative cell density in relation to $\beta$-TCP dense granules, despite the release of $\mathrm{Mg}$ from granules into the cell culture medium. Conclusion: $\beta$-TCMP granules were successfully produced and were able to release $\mathrm{Mg}$ into media without cytotoxicity, indicating the suitability of this promising material for further biological studies on its adequacy for bone therapy.
\end{abstract}

Key words: Magnesium. Bone substitutes. Biocompatibility.

\section{INTRODUCTION}

Research on bone tissue regeneration is constantly expanding due to the improved quality of life and the resulting increase in the world population's life expectancy ${ }^{10}$. The regeneration of lost or injured human osseous components is limited; when bone is subjected to extensive damage, a graft is required. Hydroxyapatite (HA) and tricalcium phosphate (TCP) are the most common synthetic biomaterials used as bone grafts, especially in the field of oral and craniofacial surgery, due to their similarity to the mineral phase of the bone. There are two major distinct phases of tricalcium phosphate crystals: $\alpha$-TCP and $\beta$-TCP.
In spite of their similar chemical composition, their different crystallographic features result in different resorption patterns: $\alpha$-TCP is obtained by heating above $1170^{\circ} \mathrm{C}$ and is more soluble than $\beta$-TCP. In addition, $\beta$-TCP is more stable at room temperature than $\alpha-T C P$, it presents higher solubility than HA and, consequently, can be degraded faster in the body, allowing a desirable gradual replacement by the newly formed bone ${ }^{2,8,13}$.

Due to the $\beta$-TCP instability in water, the most common method to obtain tricalcium phosphate is the wet precipitation of a calcium-deficient apatite (CDA) followed by heat treatment in the range of $700-1170^{\circ} \mathrm{C}^{9,16,24}$. Studies concerning $\beta$-TCP efficiency as a bone graft were already 
conducted. In vivo studies with $\beta$-TCP implanted in the rat femoral condyle were conducted by Kondo, et al. ${ }^{14}$ (2005), concluding that $\beta$-TCP has a good biocompatibility, since both bioresorption and bone formation started at an early phase after implantation. Shiratori, et al. ${ }^{26}$ (2005) also considered $\beta$-TCP an osteoconductive biomaterial, based on the histological and molecular findings of bone tissue withdrawn from bone defects in rat femurs previously implanted with $\beta$-TCP granules.

Synthetic bone grafts are basically made of calcium phosphate ceramics and, nowadays, research is being directed to calcium phosphates partially substituted by several ions in order to improve the material's properties'. Among all substituting cations, magnesium $(\mathrm{Mg})$ is of special importance. Briefly, it is the fourth most abundant cation in the body, the second most abundant in intracellular medium and the most abundant (around $6 \mathrm{~mol} \%$ ) in cartilage and bone tissue during the initial stages of osteogenesis. $\mathrm{Mg}$ is an essential cofactor in many biochemical reactions involving ATP as second substrate. In addition, $\mathrm{Mg}$ is mitogenic for osteoblasts and its depletion causes inhibition of cell growth in vitro due to the resulting reduction in the synthesis of DNA, RNA and proteins. Dietary $\mathrm{Mg}$ deficiency is associated with risk of osteoporosis and it also plays an important role in many enzymatic reactions. Additionally, $\mathrm{Mg}$ incorporation into TCP crystal lattice reduces the crystallinity of the material and therefore accelerates the degradation process, which may favor bone formation by the osteoblasts ${ }^{17,23,29}$.

To date, there are very few biological studies about Mg-substituted $\beta$-TCP, also known as $\beta$-TCMP. Sader, LeGeros and Soares ${ }^{24}$ (2009) cultivated human osteoblast cells onto sintered tablets of $\beta$-TCP and $\beta$-TCMP ( $\mathrm{Mg} / \mathrm{Ca}=0.2 \mathrm{~mol})$ for $4 \mathrm{~h}, 24$ $\mathrm{h}$ and 7 days. The results showed greater cell proliferation on $\beta$-TCMP when compared to $\beta$-TCP. However, it was recently assumed that part of the Mg could be adsorbed onto the material's surface, since the maximum substitution of $\mathrm{Mg}$ for calcium (Ca) in the structure of TCP is $0.15 \mathrm{~mol}^{1}$. Therefore, the aim of this study was to produce dense granular $\beta$-TCP and $\beta$-TCMP $(\mathrm{Mg} / \mathrm{Ca}=0.15 \mathrm{~mol})$ in order to investigate $\beta$-TCMP biocompatibility by means of an in vitro cytotoxicity assay that evaluates two different parameters of cell survival and integrity.

\section{MATERIAL AND METHODS}

\section{$\beta$-TCP and $\beta$-TCMP granules preparation}

Mg-substituted calcium deficient apatite (MgCDA) containing $0.15 \mathrm{~mol}$ of $\mathrm{Mg}$ was synthesized by the wet precipitation method as previously described by Sader, LeGeros and Soares ${ }^{24}$ (2009). Briefly, a solution containing $1.3 \mathrm{M} \mathrm{Ca}(\mathrm{OH})_{2}(96 \%$ pure, Merck, Darmstadt, Germany) and 0.17 M $\mathrm{MgCl}_{2} \cdot 6 \mathrm{H}_{2} \mathrm{O}$ (Merck) was simultaneously introduced with a $0.17 \mathrm{M} \mathrm{H}_{3} \mathrm{PO}_{4}$ (85\% pure, Merck) solution into water over $3 \mathrm{~h}$, with constant heating at $39^{\circ} \mathrm{C}$ and $\mathrm{pH}$ equal to 9 . The obtained powder and the commercial product tricalcium phosphate ( $\beta$-TCP, dried extra pure; Merck) were then uniaxially pressed into cylindrical tablets under a compressive pressure of $216 \mathrm{MPa}$, followed by sintering at $1000^{\circ} \mathrm{C}$ for $4 \mathrm{~h}$ in open air. The tablets were crushed and sieved to select the dense granules in the range of 250-500 $\mu \mathrm{m}$.

\section{Physicochemical characterization}

The phases presented in the granular materials were analyzed using an X-ray diffractometer (XRD; Shimadzu XRD 6000, Japan) with monochromatized $\mathrm{Cu}$ ka radiation and operational tube with $40 \mathrm{kV}$ and $30 \mathrm{~mA}$. The resulting trace was analyzed and compared with the standard library of known diffraction patterns (JCPDS). The samples mixed with $\mathrm{KBr}$ (99.9\% pure, Sigma Aldrich, St. Louis, MO, USA) in the proportion of 1:20 were also examined by Fourier-transformed infrared spectroscopy (FTIR; PerkinElmer, Spectrum 100, Norfolk, VA, USA) in order to identify the vibration modes of the molecules in the range of $500-4000 \mathrm{~cm}^{-1}$. For XRD and FTIR analysis, the granules were crushed prior to use.

Calcium, phosphorus $(\mathrm{P})$ and $\mathrm{Mg}$ contents in both phosphates were determined by inductively coupled plasma optical emission spectroscopy (ICP; PerkinElmer Optima 3000, USA). The analysis was performed in triplicate, and the mean values and standard deviations were subjected to one-way ANOVA and Tukey's post-test test $(p<0.05)$. Scanning electron microscopy allowed the morphological characterization of the granules (SEM; JEOL JSM 6460-LV, Japan).

\section{Cytotoxicity assay}

Samples were extracted from culture medium (100 mg of TCP granules/mL of DMEM) at $37^{\circ} \mathrm{C}$ for $24 \mathrm{~h}$ and the extracts were collected for cytotoxicity assay according to ISO 10993-12:200711 and 7405:2008 ${ }^{12}$. ICP analysis was performed in triplicate to determine the $\mathrm{Ca}$ and $\mathrm{Mg}$ content dissolved in the culture medium for $24 \mathrm{~h}$ (biomaterial extract). A $1 \%$ phenol solution was used as positive control for cytotoxicity, while untreated cells were used as a negative control (cultivated with DMEM only). Subsequently, MC3T3 pre-osteoblasts (CRL 2594 - ATCC) were seeded in 96-well cell culture plates ( $1 \times 10^{4} /$ well) and subcultured in DMEM containing ampicillin $(0.025 \mathrm{~g} / \mathrm{L})$, streptomycin $(0.1 \mathrm{~g} / \mathrm{L})$ and supplemented with $10 \%$ fetal bovine serum for 24 $\mathrm{h}$ at $37^{\circ} \mathrm{C}$ and $5 \% \mathrm{CO}_{2} / 95 \%$ air.

After $24 \mathrm{~h}$ of cell exposure to each extract 
medium, cell viability was evaluated with a commercial kit (In Cytotox, Xenometrix, Germany) by two different tests of cell survival and integrity on the same sample: 2,3-bis[2-methyloxy-4 nitro-5sulfophenyl]-2H-tetrazolium-5-carboxanilide (XTT) and crystal violet dye elution (CVDE).

The XTT cell proliferation assay is based on the ability of mitochondrial dehydrogenase enzymes to convert the yellow water-soluble tetrazolium salt XTT into orange colored soluble compounds of formazan, measured by their absorbance at $480 \mathrm{~nm}^{25}$. The CVDE assay evaluates cell density by staining DNA and the absorbance at $540 \mathrm{~nm}$ is proportional to the amount of cells in each well ${ }^{15}$. The absorbance data were obtained with a microplate UV/Vis spectrophotometer (PowerWave MS2, BioTek Instruments, Winooski, VT, USA). All the tests were performed in quintuplicate.

Normal distribution was confirmed by a D'Agostino-Pearson omnibus test. Mean values and standard deviations were submitted to oneway ANOVA and Tukey's post-hoc test considering statistical significance at $p<0.05$.

\section{RESULTS}

As shown in Figure 1, the diffraction pattern of granules obtained from the commercial TCP showed the mean peaks of $\beta$-TCP or whitlockite (JCPDS 090169); on the other hand, the diffractogram of granules produced with Mg-CDA presented the mean peaks of $\beta$-TCMP or magnesia whitlockite (JCPDS 130404). Regarding the morphology of the granules, a lower surface roughness was verified on $\beta$-TCMP when compared to $\beta$-TCP granules on SEM images (Figure 2).

The FTIR spectra in Figure 3 showed phosphate

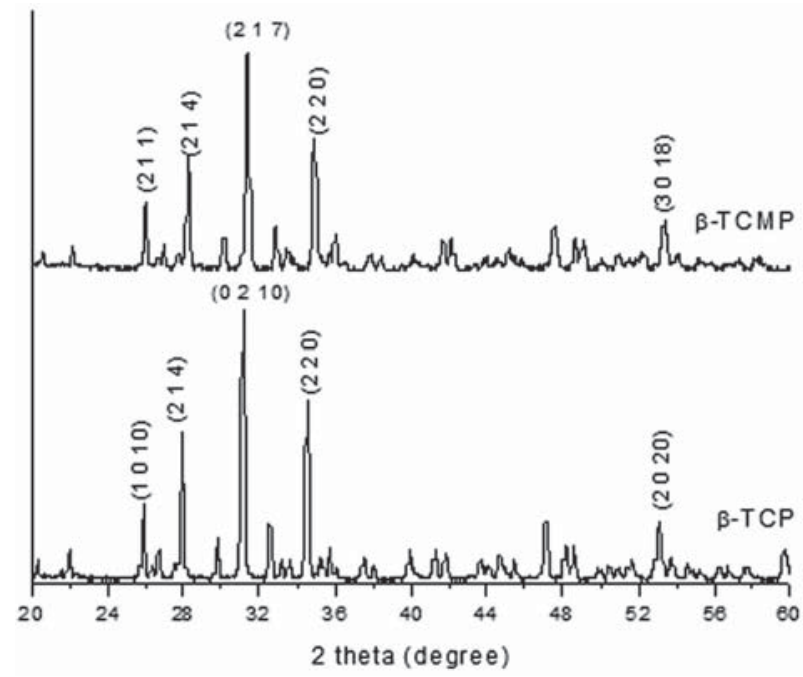

Figure 1- X-ray diffraction (XRD) patterns of tricalcium phosphate $(\beta-\mathrm{TCP})$ and magnesium-substituted $\beta$-TCP $\left(\beta\right.$-TCMP) heat-treated at $1000^{\circ} \mathrm{C}$ in air for $4 \mathrm{~h}$ bands at 1126 and 1025 (v3) $\mathrm{cm}^{-1}$, as well as at 604 and $554(\mathrm{n} 4) \mathrm{cm}^{-1}$ in both materials, which are characteristic of tricalcium phosphates. Based on ICP results, the $(\mathrm{Ca}+\mathrm{Mg}) / \mathrm{P}$ molar ratio of $\beta$-TCMP was calculated to be 1.45 , containing $0.14 \mathrm{~mol}$ of $\mathrm{Mg}$, which is close to the theoretical values $[(\mathrm{Ca}+\mathrm{Mg}) / \mathrm{P}=1.5$ and $0.15 \mathrm{~mol}$ of $\mathrm{Mg}]$. Also, the $\mathrm{Ca} / \mathrm{P}$ ratio of $\beta$-TCP was 1.38 .

In relation to DMEM alone, the ICP analysis of the $\beta$-TCMP granule extract medium (DMEM) showed that there was a significant decrease in the Ca concentration in opposition to an increase $(p<0.05)$ in $\mathrm{Mg}$ (Figure 4).

The results of in vitro cytotoxicity tests for $\beta$-TCP and $\beta$-TCMP granules from XTT and CVDE viability assays are in Figure 5. Mitochondrial activity was similar in the cells exposed to $\beta$-TCP and $\beta$-TCMP extracts and in the untreated cells (control group) but, as expected, $1 \%$ phenol abolished all dehydrogenase activity in the treated cells (positive

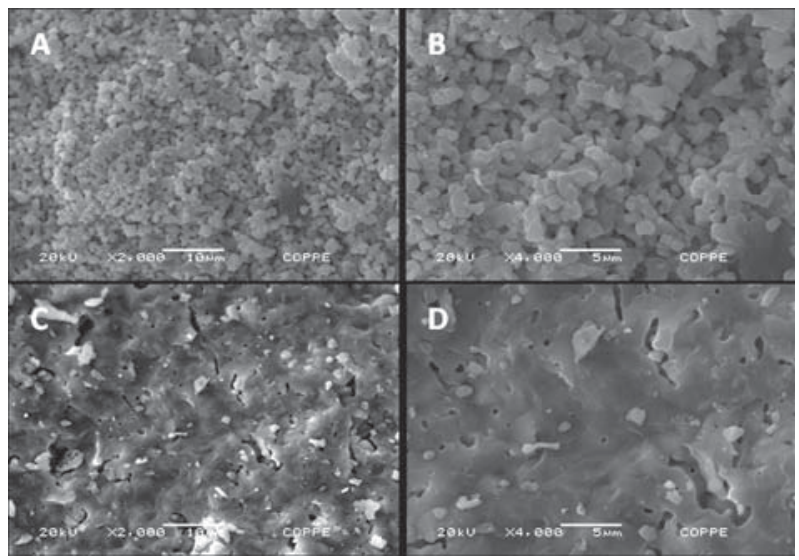

Figure 2- Scanning electron microscopy (SEM) images of tricalcium phosphate granules $(250-500 \mu \mathrm{m})$ : $\beta$-TCP $(A ; B)$ and magnesium-substituted $\beta$-TCP $(\beta-$ TCMP) $(C ; D)$

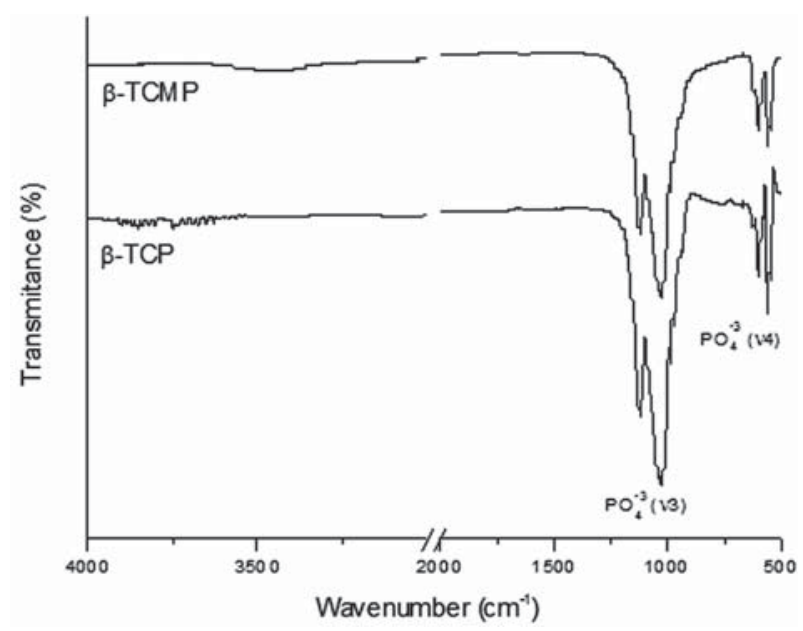

Figure 3- FTIR spectra of tricalcium phosphate ( $\beta$-TCP) and magnesium-substituted $\beta$-TCP heat-treated at $1000^{\circ} \mathrm{C}$ in air for $4 \mathrm{~h}$ 


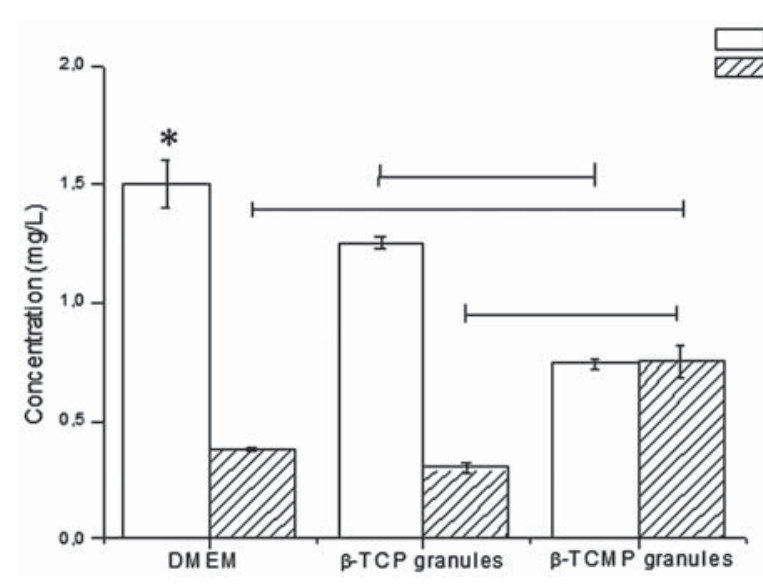

Figure 4- Calcium (Ca) and magnesium $(\mathrm{Mg})$ contents of $\beta$-TCP and $\beta$-TCMP granule extracts or cell culture medium (DMEM) determined by ICP analysis, expressed as means and corresponding standard deviations. Bars and asterisks indicate significant differences $(p<0.05$, ANOVA)
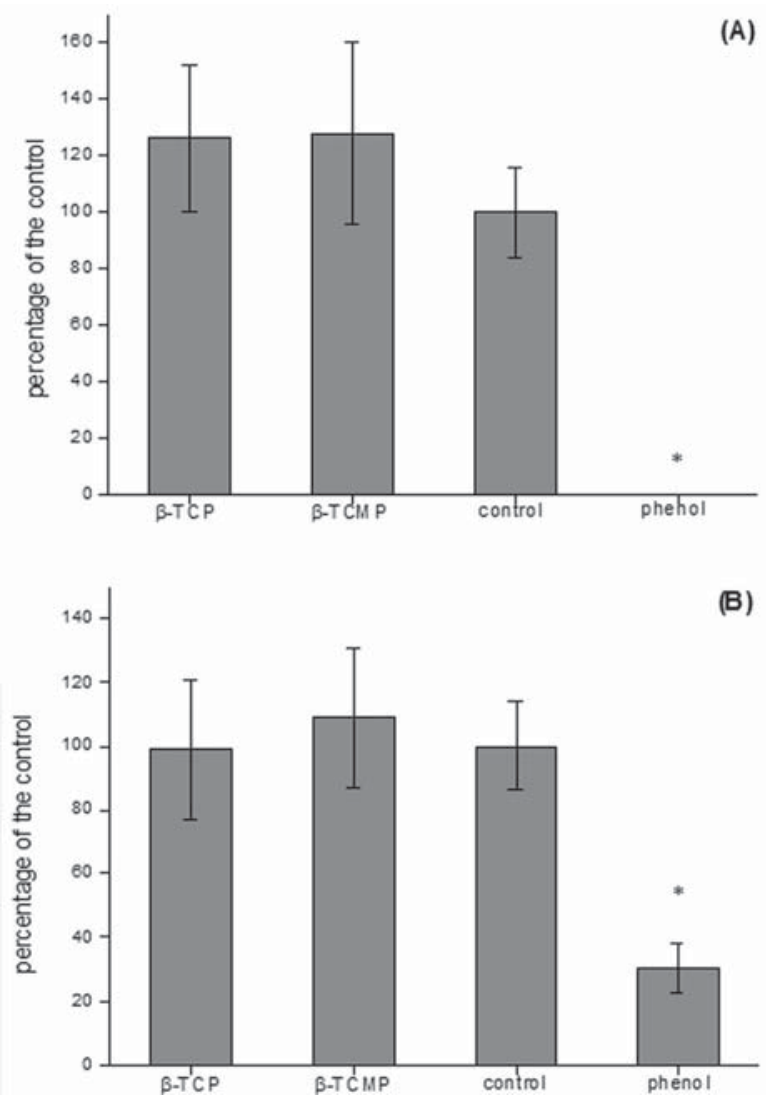

Figure 5- Cytotoxicity assay of tricalcium phosphate ( $\beta$-TCP) and magnesium-substituted $\beta$-TCP on mouse osteoblasts, indicated as means and corresponding standard deviations. (A) 2,3-bis[2-methyloxy-4 nitro5-sulfophenyl]-2H-tetrazolium-5-carboxanilide reduction. (B) Crystal Violet dye elution. The asterisk indicates that the phenol group presented a significantly lower absorbance than all other groups $(p<0.05$, ANOVA) control). Similar behavior was observed for the crystal violet test with no statistical difference between the biomaterials, but a strong reduction in the DNA content of cells in the phenol-treated group. Additionally, the results of both tests reveal that the overall viability of the cells exposed to the biomaterial extracts did not decrease, when compared with the untreated cells.

\section{DISCUSSION}

The treatment of large bone fractures still remains a challenge for dental and medical professionals because of many factors such as, biomaterials lacking adequate physicochemical or biological characteristics, e.g. bioresorption, even those of natural origin ${ }^{5,22}$. Recently, research has been performed in the field of engineered polymer scaffolds to be used as structural bone substitutes. The incorporation of calcium phosphate into these scaffolds could improve their efficacy as bone grafts. The slow degradation of calcium phosphate materials compared with a number of polymers should maintain the material's stability during the bone formation phase, and rapid degradation of the material would be no longer an important issue ${ }^{28}$. In spite of the myriad of materials being developed and tested in the last decades, the ideal biomaterial has not yet been developed, and research must be conducted to investigate physicochemical and biological improvements to the currently available repertoire of biomaterials. In this context, the present work showed the synthesis and characterization of dense granules of $\beta$-TCMP, a novel biomaterial aiming to associate the osteoconductivity of $\beta$-TCP and the stimulatory effect of $\mathrm{Mg}$ on osteoblasts. However, before performing in vivo studies on the impact of such material in bone tissue therapy, an in vitro evaluation of cytocompatibility should be conducted.

$\mathrm{Mg}$ incorporation into TCP granules reflected in the shift of the XRD peaks due to partial Mg-for-Ca substitution, causing a contraction in the unit cell dimension and stabilizing the structure. This effect is attributed to the smaller ionic radius of $\mathrm{Mg}(0.65$ $\AA)$ in relation to $\mathrm{Ca}(0.99 \AA)$ since substitutions with smaller ions give rise to lattice strain, favoring the contraction and at the same time stabilizing the structure ${ }^{27}$. This was proven when SEM images were observed: due to the higher volumetric contraction of $\beta$-TCMP, a different level of densification was observed, consequently leading to a variation on surface microporosity between $\beta$-TCMP and $\beta$-TCP granules, as already reported ${ }^{24}$. The FTIR spectra exhibit the characteristic bands of tricalcium phosphate $\left[\mathrm{Ca}_{3}\left(\mathrm{PO}_{4}\right)_{2}\right]$, attesting the accuracy of the biomaterial synthesis ${ }^{9,16,24}$.

ICP analysis showed that there was release 
of $\mathrm{Mg}$ and precipitation of $\mathrm{Ca}$ into the $\beta$-TCMP granule extract, when compared to the composition of DMEM. The material's solubility is a vital characteristic since in vivo resorption is controlled by two factors: its own dissolution into the medium and cell-mediated degradation. Li, et al. ${ }^{18}$ (2008) immersed b-TCMP powders doped with 0, 2.3, 4.9, 7.3 and $10.1 \%$ of $\mathrm{Mg}$ in a buffer solution of $0.08 \mathrm{M}$ $\mathrm{CH}_{3} \mathrm{COOH}-\mathrm{CH}_{3} \mathrm{COONa}\left(\mathrm{pH} 5.5\right.$ ) at $25^{\circ} \mathrm{C}$ for up to 27 months. It was observed that the reduced solubility of the material with increasing $\mathrm{Mg}$ content could be attributed to the greater structural stability: the $\beta$-TCP structure can accommodate ions with an ionic radius in the range of $0.06-0.08 \mathrm{~nm}$ (the ionic radius of $\mathrm{Mg}$ is $0.072 \mathrm{~nm}$ ).

Biocompatibility is defined as the ability of a biomaterial to perform in the context of a suitable host response in a particular application. Hence, metallic ions released in excess by a biomaterial can be toxic if they induce undesirable changes at higher concentrations ${ }^{6,7}$. Lima, et al. ${ }^{20}$ (2011) assessed the number of viable Balb/c 3T3 fibroblasts after exposure to several metal-modified apatite extracts for $24 \mathrm{~h}$ and concluded that cells respond to the metal that substitutes $\mathrm{Ca}$ or phosphate ions in the crystal lattice of HA. For that reason, soluble biomaterials such as metallic ion-substituted calcium phosphates must be evaluated in terms of their cytocompatibility before clinical use. The general screening assays for biomaterial testing are divided into four phases: general toxicity (in vitro cytotoxicity tests), local tissue irritation (animal implantation), pre-clinical (proof of concept in animal model) and clinical evaluation (human trials). In vitro cytotoxicity assays provide a measure of cell death caused by biomaterials or their extracts and it is important to recognize the limitations of each test to formulate an appropriate judgment ${ }^{21}$. For instance, metabolic impairment tests (XTT) are more complex and can be biased by bacterial contamination and are prone to overestimating cell viability ${ }^{4}$. On the other hand, the crystal violet assay can stain dead cells that are still attached to the plate ${ }^{3}$. Nevertheless, both are important tools to predict cell growth and survival.

The XTT result shows that $\beta$-TCMP granules are cytocompatible. Concerning the CVDE assay result, considerable cell density was observed in the cells cultivated with the phenol solution. Still, those cells were in a death process since no metabolic activity was detected by the XTT assay, and yet CV also dyed the dead cells that were still attached to the plate. This reinforces the necessity to analyze more than one aspect of cell survival and integrity before attesting biomaterial cytocompatibility.

Landi, et al. ${ }^{17}$ (2008) implanted HA granules containing $5.7 \%$ of $\mathrm{Mg}$ in rabbit femoral bone defects. The osteoconductivity and resorption of the material was higher compared with commercial $\mathrm{HA}$. Another study investigated the activity of osteoclasts on $6.8 \mathrm{~mol} \% \mathrm{Mg}$-containing tricalcium phosphate discs in different $\mathrm{Mg}$-containing culture media. Even $100 \mathrm{ppm}$ of $\mathrm{Mg}$ ions in the culture medium did not increase osteoclast apoptosis and $\mathrm{Mg}$ ions in the TCP structure had no effect on osteoclast apoptosis ${ }^{19}$. Moreover, an assay using osteoblast culture indicated that the presence of $\mathrm{Mg}$ in TCP structure stabilized the cell-material interface and consequently enhanced cell attachment and growth ${ }^{30}$.

To the best of our knowledge, there are insufficient data in the literature regarding $\beta$-TCMP granules cytotoxicity assays that allow comparison of the results. However, Sader, LeGeros and Soares $^{24}$ (2009) showed that dense $\beta$-TCMP (Mg/ $\mathrm{Ca}=0.2 \mathrm{~mol}$ ) tablets could sustain the adhesion and proliferation of human osteoblast cells in vitro, suggesting that this is a promising biomaterial for bone grafting. Conversely, the reported beneficial effect could be due, at least in part, to the $\mathrm{Mg}$ adsorbed by the granule surface ${ }^{1}$.

\section{CONCLUSION}

Granular $\beta$-TCMP ( $\mathrm{Mg} / \mathrm{Ca}=0.15 \mathrm{~mol})$ was successfully produced and the resulting biomaterial was shown to be biocompatible, while being capable of releasing $\mathrm{Mg}$ in the cell culture medium. These results indicate the suitability of this promising material for further biological in vivo studies on its adequacy as an efficient bone substitute material.

\section{ACKNOWLEDGMENTS}

We thank FAPERJ, FINEP, MS/DECIT, CAPES, CAPES-COFECUB and CNPq for the financial support of this research.

\section{REFERENCES}

1- Araujo JC, Sader MS, Moreira EL, Moraes VCA, LeGeros RZ, Soares GA. Maximum substitution of magnesium for calcium sites in $\mathrm{Mg}-\beta$-TCP structure determined by $\mathrm{X}$-ray powder diffraction with the Rietveld refinement. Mater Chem Phys. 2009;118:337-40.

2- Barrère $F$, Van Blitterswijk CA, De Groot $\mathrm{K}$. Bone regeneration: molecular and cellular interactions with calcium phosphate ceramics. Int J Nanomedicine, 2006;1:317-32.

3- Chiba K, Kawakami K, Tohyama K. Simultaneous evaluation of cell viability by neutral red, MTT and crystal violet staining assays of the same cells. Toxicol In Vitro. 1998;12:251-8.

4- Ciapetti G, Granchi D, Verri E, Savarino L, Cavedagna D, Pizzoferrato A. Application of a combination of neutral red and amino black staining for rapid, reliable cytotoxicity testing of biomaterials. Biomaterials. 1996;17:1259-64.

5- Conz MB, Granjeiro JM, Soares GA. Hydroxyapatite crystallinity does not affect the repair of critical size bone defects. J Appl Oral Sci. $2011 ; 19: 337-42$. 
6- De Deus G, Canabarro A, Alves G, Linhares A, Senne MI, Granjeiro JM. Optimal cytocompatibility of a bioceramic nanoparticulate cement in primary human mesenchymal cells. J Endodont. 2009;35:1387-90.

7- Dorozhkin SV. Calcium orthophosphates. J Mater Sci. 2007;42:1061-95.

8- Ducheyne P, Radin S, King L. The effect of calcium phosphate ceramic composition and structure on in vitro behavior. I. Dissolution. J Biomed Mater Res. 1993;27:25-34.

9- Gibson IR, Rehman I, Best SM, Bonfield W. Characterization of the transformation from calcium-deficient apatite to betatricalcium phosphate. J Mater Sci Mater Med. 2000;12:799-804. 10- Habibovic P, De Groot K. Osteoinductive biomaterials properties and relevance in bone repair. J Tissue Eng Regen Med. 2007; $1: 25-32$.

11- International Organization for Standardization. ISO 1099312:2007: Biological evaluation of medical devices. Part 12: Sample preparation and reference materials. Geneva: ISO; 2007.

12- International Organization for Standardization. ISO 7405:2008: Evaluation of biocompatibility of medical devices used in dentistry. Geneva: ISO; 2008.

13- Kamitakahara M, Ohtsuki C, Miyazaki T. Review paper: behavior of ceramic biomaterials derived from tricalcium phosphate in physiological condition. J Biomater Appl. 2008;23:197-212.

14- Kondo A, Ogose A, Tokunaga K, Ito T, Arai K, Kudo N, et al. Bone formation and resorption of highly purified beta-tricalcium phosphate in the rat femoral condyle. Biomaterials. 2005;26:56008.

15- Kueng W, Silber E, Eppenberger U. Quantification of cells cultured on 96-well plates. Anal Biochem. 1989;182:16-9.

16- Kumta PN, Sfeir C, Lee DHL, Olton D, Choi D. Nanostructured calcium phosphates for biomedical applications: novel synthesis and characterization. Acta Biomater. 2005;1:65-83.

17- Landi E, Logroscino G, Proietti L, Tampieri A, Sandri M, Sprio S. Biomimetic Mg-substituted hydroxyapatite: from synthesis to in vivo behaviour. J Mater Sci Mater Med. 2008;19:239-47. 18- Li X, Ito A, Sogo Y, Wang X, LeGeros RZ. Solubility of Mgcontaining beta-tricalcium phosphate at $25^{\circ} \mathrm{C}$. Acta Biomater. 2008;5:508-17.
19- Li X, Senda K, Ito A, Sogo Y, Yamazaki A. Effect of Zn and Mg in tricalcium phosphate and in culture medium on apoptosis and actin ring formation of mature osteoclasts. Biomed Mater. 2008;4:1-8. 20- Lima IR, Alves GG, Soriano CA, Campaneli AP, Gasparoto TH, Ramos ES Jr, et al. Understanding the impact of divalent cation substitution on hydroxyapatite: an in vitro multiparametric study on biocompatibility. J Biomed Mater Res A. 2011;98:351-8.

21- Murray PE, García Godoy C, García Godoy F. How is the biocompatibility of dental biomaterials evaluated? Med Oral Patol Oral Cir Bucal. 2007;12:E258-66.

22- Paulo AO, Castro-Silva II, Oliveira DF, Machado ME, BonettiFilho I, Granjeiro JM. Repair of critical-size defects with autogenous periosteum-derived cells combined with bovine anorganic apatite/ collagen: an experimental study in rat calvaria. Braz Dent J. $2011 ; 22: 322-8$.

23- Rude RK, Gruber HE. Magnesium deficiency and osteoporosis: animal and human observations. J Nutr Biochem. 2004;15:710-6. 24- Sader MS, Legeros RZ, Soares GA. Human osteoblasts adhesion and proliferation on magnesium-substituted tricalcium phosphate dense tablets. J Mater Sci Mater Med. 2009;20:521-7. 25- Scudiero DA, Shoemaker RH, Paull KD, Monks A, Tierney S, Nofziger $\mathrm{TH}$, et al. Evaluation of a soluble tetrazolium/formazan assay for cell growth and drug sensitivity in culture using human and other tumor cell lines. Cancer Res. 1988;48:4827-33.

26- Shiratori K, Matsuzaka K, Koike Y, Murakami S, Shimono M, Inoue $\mathrm{T}$. Bone formation in beta-tricalcium phosphate-filled bone defects of the rat femur: morphometric analysis and expression of bone related protein mRNA. Biomed Res. 2005;26:51-9.

27- Tardei C, Grigore F, Pasuk I, Stoleriu S. The study of Mg2+/ $\mathrm{Ca} 2+$ substitution of beta-tricalcium phosphate. J Optoelectron Adv Mater. 2006;8:568-71.

28- Wagoner-Johnson AJ, Herschler BA. A review of the mechanical behavior of $\mathrm{CaP}$ and $\mathrm{CaP} /$ polymer composites for applications in bone replacement and repair. Acta Biomater. 2010;7:16-30. 29- Wolf FI, Cittadini A. Chemistry and biochemistry of magnesium. Mol Aspects Med. 2003;24:3-9.

30- Xue W, Dahlquist K, Banerjee A, Bandyopadhyay A, Bose S. Synthesis and characterization of tricalcium phosphate with $\mathrm{Zn}$ and Mg based dopants. J Mater Sci Mater Med. 2008;19:2669-77. 